\title{
Pengaruh Model Penyimpanan Benih dan Jumlah Biji Per Lubang Tanam Terhadap Pertumbuhan dan Hasil Jagung (Zea mays, L.)
}

\author{
Erwinus Taek Manikin ${ }^{\mathrm{a}}$, Maria Afnita Lelang ${ }^{\mathrm{b}}$ \\ ${ }^{a}$ Fakultas Pertanian, Universitas Timor, Kefamenanu, TTU - NTT, 85613, Indonesia \\ ${ }^{\mathrm{b}}$ Fakultas Pertanian, Universitas Timor, Kefamenanu, TTU - NTT, 85613, Indonesia, email: afnitalelang@ymail.com
}

\section{Article Info}

\section{Article history:}

Received 27 Agustus 2015

Received in revised form 12 Desember 2015

Accepted 11 Januari 2016

\section{Keywords:}

Jagung

Model Penyimpanan

Jumlah Biji Per Lubang Tanam

\begin{abstract}
Abstrak
Penelitian ini bertujuan untuk mengetahui pengaruh model penyimpanan dengan jumlah biji per lubang tanam yang tepat sehingga memberikan pertumbuhan dan hasil jagung yang terbaik. Percobaan lapangan menggunakan Rancangan Acak Kelompok (RAK) faktorial $3 \times 3$. Faktor yang diteliti adalah pengaruh model penyimpanan yang terdiri dari tiga aras yaitu model penyimpanan di klobot, penyimpanan di lumbung dan penyimpanan di drum. Faktor kedua adalah jumlah biji per lubang tanam yang terdiri dari tiga aras yaitu 1 biji, 2 biji dan 3 biji. Hasil penelitian menunjukkan bahwa interaksi antara model penyimpanan benih dan jumlah biji per lubang tanam hanya terjadi terhadap parameter tinggi tanaman 35 HST, panjang tongkol dan jumlah baris per tongkol. Model penyimpanan dalam klobot berpengaruh nyata terhadap diameter batang 56 HST dan panjang tongkol, sedangkan jumlah biji per lubang tanam berpengaruh nyata terhadap tinggi tanaman 56 HST, luas daun, jumlah baris per tongkol, jumlah biji per baris, jumlah tongkol per petak, berat pipilan kering per tanaman maupun per petak, berat 100 biji dan berat segar maupun kering berangkasan. Penyimpanan benih dengan cara klobot memberikan hasil jagung tertinggi sebesar 2,385 t/ha. Penanaman dengan jumlah tiga biji per lubang tanam memberikan hasil jagung tertinggi yakni 3,178 t/ha. (2016 dipublikasikan oleh Savana Cendana.
\end{abstract}

\section{Pendahuluan}

Tanaman Jagung (Zea mays, L.) merupakan komoditas yang sangat penting selain padi terutama di negara negara agraris seperti Indonesia. Jagung merupakan bahan pangan yang berperan penting dalam perekonomian, mudah diterima masyarakat, karena merupakan pangan tradisional. Jagung mempunyai peranan penting dalam hal penyediaan bahan pangan, bahan baku industri dan pakan ternak. Jagung memiliki kandungan gizi seperti karbohidrat, protein dan lemak, (Agustinus, 2008). Kandungan gizi jagung tidak kalah dengan beras atau terigu, bahkan jagung memiliki keunggulan karena merupakan pangan fungsional dengan kandungan serat pangan, unsur Fe dan beta-karoten (pro vitamin A) yang tinggi, (Suarni, 2001)

Menurut data BPS NTT (2014), pada periode 2010-2011 luas panen jagung meningkat dari 244.600 ha menjadi 246.900 ha tetapi produksinya justru menurun dari 653.600 ton menjadi 524.600 ton atau turun sebesar $19,74 \%$. Kondisi ini disebabkan menurunnya produktifitas jagung dari $25,50 \mathrm{kw} / \mathrm{ha}$ pada tahun 2009 menjadi 21,25 kw/ha pada tahun 2011 atau mengalami penurunan produktivitas rata-rata sebesar $8,34 \%$ per tahun. Maka dari itu dalam rangka mewujudkan Nusa Tenggara Timur (NTT) sebagai Provinsi jagung selain perluasan areal tanaman juga perlu perhatian serius terhadap upaya peningkatan produktivitas jagung. Hingga tahun 2014 luas panen telah mencapai 270.396 ha produktivitas meningkat hingga $26,17 \mathrm{kw} / \mathrm{ha}$ dan produksi mencapai 707.643 ton. Pada wilayah Kabupaten Timor Tengah Utara (TTU) luas panen jagung pada tahun 2014 adalah 25.114 ha dengan produktivitas $25,36 \mathrm{kw} / \mathrm{ha}$ dari hasil 63.677 ton, masih jauh lebih rendah dibanding produktivitas jagung di wilayah lain seperti Kabupaten Manggarai Timur yang produktivitasnya mencapai 32,33 $\mathrm{kw} / \mathrm{ha}$

Peningkatan produktivitas jagung dapat dilakukan dengan penerapan teknologi budidaya yang tepat misalnya penggunaan benih yang bermutu. Menurut Sutopo (2002), ketahanan benih untuk disimpan beraneka ragam tergantung dari jenis benih, cara dan tempat penyimpanan. Tempat untuk menyimpan benih juga bervariasi tergantung dari macam benih serta maksud dan lama penyimpanan.

Kebiasaan masyarakat TTU pada umumnya menyimpan hasil panen jagung termasuk untuk kebutuhan sebagai benih dengan cara pengasapan di dapur dan menyimpan di lumbung. Kebiasaan ini sudah menjadi tradisi sejak dulu, namun saat ini ada juga sebagian masyarakat yang sudah mulai menyimpan jagung di drum atau jerigen. Model penyimpanan di lumbung dan dapur dipercaya dapa meningkatkan daya simpan jagung lebih lama dan terhindar dari hama bubuk.

Menurut Subagio dan Aqil (2013), model penyimpanan jagung yang tidak efektif dapat menyebabkan kebutuhan benih menjadi kurang tersedia atau terjadi kemunduran benih sehingga benih yang ada kurang bermutu. Benih jagung yang sesuai digunakan untuk penanaman yakni benih yang baik, bijinya mengkilat dan bebas hama dan penyakit karena benih memberikan andil yang besar untuk produktifitas. Pada waktu panen, petani biasanya memilih tongkoltongkol terbaik dari tanaman terbaik untuk disimpan sebagai benih pada musim berikutnya.

Selain penggunaan benih bermutu, peningkatan produktifitas jagung dapat juga dilakukan dengan cara pengaturan jumlah benih per lubang tanam. Menurut Rinsema (1993), tanaman agar mendapatkan hasil yang tinggi perlu diusahakan ketersediaan persyaratan pertumbuhan yang sebaik-baiknya sehingga tanaman dapat tumbuh dan berkembang dengan cepat. Selanjutnya menurut Berkelaar (2001), pemakaian benih per lubang tanam berpengaruh terhadap pertumbuhan karena secara langsung berhadapan dengan kompetisi antar tanaman dalam satu rumpun. Jumlah bibit per lubang tanam yang lebih sedikit akan memberikan ruang pada tanaman untuk menyebar dan memperdalam perakaran.

Permasalahan dalam penelitian ini adalah belum diketahui tentang pengaruh model penyimpanan benih yang biasa dilakukan masyarakat TTU dan jumlah biji per lubang tanam terhadap pertumbuhan dan hasil jagung sehingga perlu dilakukan penelitian ini. Penelitian ini bertujuan untuk mengetahui pengaruh model penyimpanan dengan jumlah biji per lubang tanam yang tepat sehingga memberikan pertumbuhan dan hasil jagung yang terbaik.

\section{Metode}

2.1 Waktu dan Tempat

Penelitian dilaksanakan bulan April sampai Agustus 2015 di kebun masyarakat, KM 5, Kelurahan Maubeli, Kecamatan Kota Kefamenanu, Kabupaten TTU.

\subsection{Rancangan Percobaan}

Penelitian mengunakan Rancangan Acak Kelompok (RAK) faktorial 3 x 3 yang diulang tiga kali. Faktor pertama adalah model penyimpanan benih $(\mathrm{P})$ yang terdiri dari tiga aras yaitu penyimpanan di dapur dengan klobot (pengasapan) $\left(\mathrm{p}_{1}\right)$, penyimpan di lopo atau lumbung $\left(\mathrm{p}_{2}\right)$ dan penyimpan dalam drum atau jerigen $\left(\mathrm{p}_{3}\right)$. Faktor kedua adalah jumlah biji per lubang tanam $(\mathrm{B})$ yang terdiri dari tiga aras yaitu satu biji $\left(\mathrm{b}_{1}\right)$, dua biji $\left(\mathrm{b}_{2}\right)$ dan tiga biji $\left(\mathrm{j}_{3}\right)$. Kombinasi perlakuannya antara lain $\mathrm{p}_{1} \mathrm{~b}_{1}, \mathrm{p}_{1} \mathrm{~b}_{2}, \mathrm{p}_{1} \mathrm{~b}_{3}, \mathrm{p}_{2} \mathrm{~b}_{1}, \mathrm{p}_{2} \mathrm{~b}_{2}, \mathrm{p}_{2} \mathrm{~b}_{3}, \mathrm{p}_{3} \mathrm{~b}_{1}, \mathrm{p}_{3} \mathrm{~b}_{2}$ dan $\mathrm{p}_{3} \mathrm{~b}_{3}$.

\subsection{Pelaksanaan Penelitian}

a. Persiapan Benih

Benih yang digunakan adalah benih jagung varietas lokal putih. Benih dipilih yang baik berupa biji besar, putih mengkilat, bagian kepala tidak pecah atau rusak. Jumlah benih yang digunakan adalah 1.620 butir benih dengan perincian 540 butir berasal dari benih yang disimpan di dapur dengan pengasapan, 540 butir berasal dari benih yang disimpan di lopo atau lumbung dan 540 butir berasal dari benih yang disimpan dalam drum atau jerigen. Benih cadangan disiapkan $10 \%$ sehingga jumlah total benih yang disiapkan sebanyak 1.782 butir. Semua benih diperoleh dari masyarakat di wilayah Desa Tualele dan Desa Mamsena, Kecamatan Insana Barat.

b. Pengolahan Tanah

Tanah terlebih dahulu dibersihkan dari gulma dan vegetasi lainnya untuk selanjutnya dilakukan pengolahan. Pengolahan tanah dilakukan dengan menggunakan cangkul, kemudian dilanjutkan dengan penggemburan tanah. Lahan yang digunakan berukuran panjang $33 \mathrm{~m}$ dan lebar $17 \mathrm{~m}$ dengan luas 361 $\mathrm{m}^{2}$. Lahan dibagi dalam tiga blok dan pada masing-masing blok dibuat sembilan petak percobaan dengan ukuran panjang $5 \mathrm{~m}$ dan lebar $3 \mathrm{~m}$ dengan 15 luas $\mathrm{m}^{2}$ sehingga secara keseluruhan terdapat 27 petak. Jarak antara petak $0,5 \mathrm{~m}$ dan jarak antara blok $1 \mathrm{~m}$. Pada setiap blok, petak, tanaman sampel dan tanaman korban diberikan label menggunakan tiang bambu dan seng.

c. Aplikasi Pemupukan

Pemberian pupuk dilakukan dengan cara pembenaman pada saat 14 hari sebelum tanam. Jenis pupuk kandang yang digunakan adalah pupuk kandang sapi yang diberikan dengan dosis $10 \mathrm{t} / \mathrm{ha}$ atau $15 \mathrm{~kg}$ per petak. Total kebutuhan pupuk sebanyak $405 \mathrm{~kg}$.

d. Penanaman

Penanaman dilakukan pada saat pagi hari, dengan cara tugal sedalam \pm 3 $\mathrm{cm}$. Peyulaman dilakukan pada 2 minggu sesudah tanam. Jumlah benih yang ditanam per lubang tanam disesuaikan dengan perlakuan yakni pada sembilan petak ditanam menggunakan satu biji per lubang tanam, sembilan petak ditanam menggunakan dua biji per lubang tanam dan sembilan petak ditanam menggunakan tiga biji per lubang tanam. Jarak tanam antar barisan $75 \mathrm{~cm}$ dan dalam barisan $50 \mathrm{~cm}$. Jumlah tanaman dalam setiap petak adalah 35 tanaman dengan jumlah keseluruhan 945 tanaman. 


\section{e. Pemeliharaan}

Pemeliharaan tanaman meliputi penyiraman, penyiangan serta pengendalian hama dan penyakit tanaman. Penyiraman dilakukan pada pagi dan sore hari hingga tanah cukup basah dengan menggunakan selang. Penyiraman dilakukan hingga tanaman berumur 1-2 bulan, pada periode pembentukkan dan perkembangan buah, yaitu umur 2-3 minggu sebelum panen, penyiraman dikurangi. Penyiangan dilakukan apabila ada gulma yang tumbuh agar tidak mengganggu pertumbuhan tanaman jagung. Pada 70 hari tanaman diserang hama lalat kecil dan pembasmi hama menggunakan pestisida organik.

f. Panen

Panen jagung dilakukan dengan kriteria tongkol atau klobot sudah mengering, biji mengkilap, keras dan bila ditekan dengan kuku tidak membekas serta terlihat ada lapisan hitam (black layer) pada bagian pangkal biji yang menempel pada tongkol. Panen dilakukan saat umur tanaman jagung 110 hari setelah tanam (HST).

\subsection{Parameter Pengamatan}

a. Tinggi Tanaman $(\mathrm{cm})$

Tinggi tanaman diukur dengan cara daun ditegakkan, diukur dari pangkal batang sampai daun paling tinggi, pengukuran menggunakan pengaris centimeter. Pengukuran dilakukan pada lima tanaman sampel saat berumur 14 HST, 35 HST dan 56 HST.

b. Diameter Batang ( $\mathrm{mm})$

Diameter batang diukur menggunakan jangka sorong dengan cara menjepit pada bagian batang ( $2 \mathrm{~cm}$ di atas pangkal batang) dari lima tanaman sampel. Pengukuran dilakukan pada saat tanaman berumur 14 HST, 35 HST dan 56 HST.

c. Luas Daun $\left(\mathrm{cm}^{2}\right)$

Luas daun diukur pada saat tanaman mencapai pertumbuhan vegetatif maksimum (56 HST). Pengukuran luas daun dilakukan menggunakan metode fotografi dengan cara mengambil semua daun pada tiga tanaman korban pada tiap petak, kemudian daun dipotret menggunakan kamera digital. Luas area daun kemudian dihitung menggunakan program ImageJ versi 1.410

d. Jumlah Tongkol Per Tanaman

Diukur dengan cara menghitung tongkol yang dihasilkan setiap tanaman pada lima tanaman sampel.

e. Panjang Tongkol $(\mathrm{cm})$

Panjang tongkol diukur pada semua tongkol yang terbentuk dari lima tanaman sampel kemudian dirata-ratakan. Penggukuran panjang tongkol menggunakan mistar $30 \mathrm{~cm}$, dan diukur dari pangkal hingga ujung tongkol.

f. Diameter Tongkol $(\mathrm{cm})$

Pengukuran diameter tongkol dilakukan pada semua tongkol yang terbentuk dari lima tanaman sampel kemudian dirata-ratakan. Pengukuran diameter tongkol menggunakan jangka sorong pada pangkal, tenggah dan ujung setiap tongkol

g. Jumlah Baris Per Tongkol

Jumlah baris per tongkol diperoleh dengan cara menghitung barisan biji yang terdapat pada setiap tongkol tanaman sampel kemudian dirata-ratakan.

h. Jumlah Biji Per Baris

Jumlah biji per baris diperoleh dengan cara menghitung semua biji dalam baris pada setiap tongkol tanaman sampel kemudian dirata-ratakan.

i. Jumlah Tongkol Per Petak

Diukur dengan cara menghitung tongkol yang dihasilkan tanaman pada setiap petak kemudian dikonversikan ke jumlah tongkol per hektar.

j. $\quad$ Berat Pipilan Kering Per Tanaman $(g)$

Berat pipilan kering per tanaman diperoleh dengan cara menimbang semua biji dari lima tanaman sampel pada setiap petak yang telah dijemur selama satu minggu.

\section{k. Berat 100 Biji (g)}

Diukur dengan cara menimbang 100 biji yang diambil secara acak dari setiap petak yang telah dijemur selama satu minggu. Penimbangan dilakukan tiga kali kemudian dirata-ratakan.

1. Berat Pipilan Kering Per Petak (t/ha)

Berat pipilan kering per petak diperoleh dengan cara menimbang semua biji pada setiap petak yang telah dijemur selama satu minggu kemudian dikonversikan ke satuan $\mathrm{t} / \mathrm{ha}$.

m. Berat Segar Berangkasan(t/ha)

Berat segar berangkasan diukur dengan cara menimbang berangkasan segar semua tanaman dalam setiap petak yang telah dipanen dan kemudian dikonversikan ke satuan t/ha.

n. Berat Kering Berangkasan(t/ha)

Berat kering berangkasan diukur dengan cara menimbang berangkasan semua tanaman dalam setiap petak yang telah dipanen dan dijemur selama satu minggu kemudian dikonversikan ke satuan t/ha.

o. Indeks Panen (\%)

Indeks panen dihitung dengan cara membandingkan berat bagian tanaman yang bernilai ekonomis dengan berat bagian seluruh tanaman kemudian dikonversikan ke satuan \%. Indeks panen dihitung dengan rumus.

$$
I P=\frac{A}{A+B} X 100 \%
$$

Keterangan

$$
\text { IP : Indeks Panen (\%) }
$$

\section{A : Berat Kering Pipilan Per Petak (t/ha)}

B : Berat Kering Brangkasan(t/ha)

\subsection{Analisis Data}

Data hasil pengamatan kemudian dianalisis dengan menggunakan sidik ragam (Anova) Rancangan Acak Kelompok (RAK). Rata-rata perlakuan selanjutnya diuji lanjut dengan menggunakan Duncan Multiple Range Test (DMRT) dengan tingkat signifikan 5\% sesuai petunjuk Gomez dan Gomez (1995). Analisis data menggunakan program SAS 9.1.

\section{Hasil dan Pembahasan}

\subsection{Tinggi Tanaman}

Tanaman terus bertambah tinggi selama penelitian. Hasil sidik ragam (Anova) menunjukkan interaksi model penyimpanan benih dan jumlah biji per lubang tanam berpengaruh secara nyata terhadap tinggi tanaman 35 HST dimana tanaman yang benihnya disimpan dengan cara klobot kemudian ditanam dengan jumlah satu biji per lubang tanam paling tinggi dan berbeda nyata dengan tinggi tanaman yang benihnya disimpan dalam lumbung kemudian ditanam dengan jumlah satu biji per lubang tanam dan tanaman yang benihnya disimpan dalam drum kemudian ditanam dengan jumlah dua biji per lubang tanam tetapi tidak berbeda nyata dengan tinggi tanaman pada kombinasi perlakuan yang lainnya. Pada pengamatan 56 HST tidak terjadi interaksi antara model penyimpanan benih dan jumlah biji per lubang tanam tetapi hasil uji lanjut menunjukkan bahwa tanaman yang benihnya disimpan dalam drum kemudian ditanam dengan jumlah satu biji per lubang tanam paling tinggi dan berbeda nyata dengan tinggi tanaman yang benihnya disimpan dalam drum kemudian ditanam dengan jumlah dua biji per lubang tanam tetapi tidak berbeda nyata dengan tinggi tanaman pada kombinasi perlakuan yang lainnya.

\section{Tabel 1. Tinggi Tanaman (cm)}

\begin{tabular}{cccccc}
\hline \multirow{2}{*}{ Waktu } & Model & \multicolumn{3}{c}{ Jumlah Biji Per Lubang Tanam } & \multirow{2}{*}{ Rerata } \\
\cline { 2 - 5 } & Penyimpanan & Satu & Dua & Tiga & \\
\hline \multirow{3}{*}{14 HST } & Klobot & $44,8 \mathrm{a}$ & $46,1 \mathrm{a}$ & $44,9 \mathrm{a}$ & $45,3 \mathrm{a}$ \\
& Lumbung & $42,5 \mathrm{a}$ & $43,1 \mathrm{a}$ & $45,5 \mathrm{a}$ & $43,7 \mathrm{a}$ \\
& Drum & $44,0 \mathrm{a}$ & $42,7 \mathrm{a}$ & $44,4 \mathrm{a}$ & $43,7 \mathrm{a}$ \\
\cline { 2 - 5 } & Rerata & $43,8 \mathrm{a}$ & $44,0 \mathrm{a}$ & $45,0 \mathrm{a}$ & $(-)$ \\
\hline \multirow{3}{*}{35 HST } & Klobot & $151,0 \mathrm{a}$ & $144,2 \mathrm{ab}$ & $137,0 \mathrm{ab}$ & $144,1 \mathrm{a}$ \\
& Lumbung & $131,7 \mathrm{~b}$ & $139,9 \mathrm{ab}$ & $148,9 \mathrm{a}$ & $140,2 \mathrm{a}$ \\
& Drum & $144,5 \mathrm{ab}$ & $129,0 \mathrm{~b}$ & $137,8 \mathrm{ab}$ & $137,1 \mathrm{a}$ \\
\hline \multirow{3}{*}{$56 \mathrm{HST}$} & Rerata & $142,4 \mathrm{a}$ & $137,7 \mathrm{a}$ & $141,2 \mathrm{a}$ & $(+)$ \\
\cline { 2 - 5 } & Klobot & $253,1 \mathrm{a}$ & $245,1 \mathrm{ab}$ & $240,0 \mathrm{ab}$ & $246,1 \mathrm{a}$ \\
& Lumbung & $240,5 \mathrm{ab}$ & $226,5 \mathrm{ab}$ & $250,2 \mathrm{a}$ & $239,0 \mathrm{a}$ \\
& Drum & $254,0 \mathrm{a}$ & $217,5 \mathrm{~b}$ & $236,7 \mathrm{ab}$ & $236,1 \mathrm{a}$ \\
\hline & Rerata & $249,2 \mathrm{a}$ & $229,7 \mathrm{~b}$ & $242,3 \mathrm{ab}$ & $(-)$ \\
\hline Keterangan & Angka pada baris dan kolom yang diikuti dengan huruf yang sama
\end{tabular}

Angka pada baris dan kolom yang diikuti dengan huruf yang sama tidak berbeda nyata menurut uji DMRT $\alpha$ 5\%.. ( + ) : Terjadi interaksi antar faktor

Model penyimpanan benih tidak berpengaruh secara nyata terhadap tinggi tanaman, meskipun demikian data Tabel 1. menunjukkan bahwa tanaman yang benihnya disimpan dengan model penyimpanan klobot selalu cenderung lebih tinggi setiap waktu pengamatan. Jumlah biji per lubang tanam juga tidak berpengaruh nyata terhadap tinggi tanaman 14 HST dan 35 HST, saat pengamatan 14 HST tanaman yang ditanam dengan jumlah tiga biji per lubang tanam cenderung lebih tinggi tetapi saat pengamatan 35 HST tanaman yang ditanam dengan jumlah satu biji per lubang tanam cenderung lebih tinggi. Pada pengamatan $56 \mathrm{HST}$, jumlah biji per lubang tanam secara nyata berpengaruh terhadap tinggi tanaman dimana tanaman yang ditanam dengan jumlah satu biji per lubang tanam paling tinggi dan berbeda nyata dengan tinggi tanaman yang ditanam dengan jumlah dua biji per lubang tanam tetapi tidak berbeda nyata dengan tinggi tanaman yang ditanam dengan jumlah tiga biji per lubang tanam.

\subsection{Diameter Batang}

Batang tanaman terus bertambah besar selama penelitian. Hasil sidik ragam (Anova) menunjukkan bahwa tidak terjadi pengaruh interaksi antara model penyimpanan benih dan jumlah biji per lubang tanam terhadap diameter batang setiap waktu pengamatan.

Model penyimpanan benih tidak berpengaruh secara nyata terhadap diameter batang saat pengamatan 14 HST dan 35 HST, meskipun demikian data Tabel 2. menunjukkan bahwa tanaman yang benihnya disimpan dengan model penyimpanan klobot selalu cenderung selalu lebih tinggi, selanjutnya pada pengamatan 56 HST model penyimpanan benih berpengaruh secara nyata terhadap diameter batang dimana tanaman yang benihnya disimpan dengan model penyimpanan klobot berbatang paling besar dan berbeda nyata dengan diameter batang tanaman yang benihnya disimpan dalam lumbung tetapi tidak berbeda nyata dengan diameter batang tanaman yang benihnya disimpan dalam drum. Jumlah biji per lubang tanam tidak berpengaruh nyata terhadap diameter batang tanaman setiap waktu pengamatan. Saat pengamatan 14 HST, diameter batang tanaman yang ditanam dengan jumlah tiga biji per lubang tanam cenderung lebih besar dan pada pengamatan selanjutnya diameter batang tanaman yang ditanam dengan jumlah tiga biji per lubang tanam tetap lebih besar dan sama dengan diameter batang tanaman yang ditanam dengan jumlah satu biji per lubang tanam. 
Tabel 2. Diameter Batang (mm)

\begin{tabular}{|c|c|c|c|c|c|}
\hline \multirow{2}{*}{ Waktu } & \multirow{2}{*}{$\begin{array}{c}\text { Model } \\
\text { Penyimpanan }\end{array}$} & \multicolumn{3}{|c|}{ Jumlah Biji Per Lubang Tanam } & \multirow{2}{*}{ Rerata } \\
\hline & & Satu & Dua & Tiga & \\
\hline \multirow{4}{*}{14 HST } & Klobot & $0,4 \mathrm{a}$ & $0,3 \mathrm{a}$ & $0,4 \mathrm{a}$ & $0,4 \mathrm{a}$ \\
\hline & Lumbung & $0,3 \mathrm{a}$ & $0,4 \mathrm{a}$ & $0,4 \mathrm{a}$ & $0,4 \mathrm{a}$ \\
\hline & Drum & $0,4 \mathrm{a}$ & $0,3 \mathrm{a}$ & $0,4 \mathrm{a}$ & $0,3 \mathrm{a}$ \\
\hline & Rerata & $0,3 \mathrm{a}$ & $0,3 \mathrm{a}$ & $0,4 \mathrm{a}$ & $(-)$ \\
\hline \multirow{4}{*}{35 HST } & Klobot & $1,3 \mathrm{a}$ & $1,3 \mathrm{a}$ & $1,1 \mathrm{a}$ & $1,3 \mathrm{a}$ \\
\hline & Lumbung & $1,0 \mathrm{a}$ & $1,1 \mathrm{a}$ & $1,2 \mathrm{a}$ & $1,1 \mathrm{a}$ \\
\hline & Drum & $1,2 \mathrm{a}$ & $1,0 \mathrm{a}$ & $1,2 \mathrm{a}$ & $1,1 \mathrm{a}$ \\
\hline & Rerata & $1,2 \mathrm{a}$ & $1,1 \mathrm{a}$ & $1,2 \mathrm{a}$ & $(-)$ \\
\hline \multirow{4}{*}{56 HST } & Klobot & $2,1 \mathrm{a}$ & $2,0 \mathrm{a}$ & $2,1 \mathrm{a}$ & $2,1 \mathrm{a}$ \\
\hline & Lumbung & $1,8 \mathrm{a}$ & $1,9 \mathrm{a}$ & $2,0 \mathrm{a}$ & $1,9 \mathrm{~b}$ \\
\hline & Drum & $2,1 \mathrm{a}$ & $1,8 \mathrm{a}$ & $2,0 \mathrm{a}$ & $2,0 \mathrm{ab}$ \\
\hline & Rerata & $2,0 \mathrm{a}$ & $1,9 \mathrm{a}$ & $2,0 \mathrm{a}$ & $(-)$ \\
\hline K & $\begin{array}{l}\text { Angka pad } \\
\text { tidak berbe } \\
\text { interaksi an }\end{array}$ & $\begin{array}{l}\text { dan } \\
\text { ta me } \\
\text { tor }\end{array}$ & g diik & an hu & $\begin{array}{l}\text { g sama } \\
\text { terjadi }\end{array}$ \\
\hline
\end{tabular}

3.3 Luas Daun

Hasil sidik ragam (Anova) menunjukkan tidak terjadi pengaruh interaksi antara model penyimpanan benih dan jumlah biji per lubang tanam terhadap luas daun tetapi hasil uji lanjut menunjukkan bahwa permukaan daun tanaman yang benihnya disimpan dengan cara klobot kemudian ditanam dengan jumlah tiga biji per lubang tanam paling luas dan berbeda nyata dengan luas daun tanaman dari kombinasi perlakuan yang lainnya tetapi tidak berbeda nyata dengan luas daun tanaman yang benihnya disimpan dalam lumbung kemudian ditanam dengan jumlah dua biji per lubang tanam.

Model penyimpanan benih juga tidak berpengaruh secara nyata terhadap luas daun tetapi data Tabel 3. menunjukkan bahwa tanaman yang sebelum ditanam benihnya disimpan dalam lumbung memiliki permukaan daun yang cenderung lebih luas dibanding tanaman yang sebelum ditanam benihnya disimpan dengan cara klobot maupun dalam drum yang permukaan daunnya paling sempit. Sebaliknya jumlah biji per lubang tanam berpengaruh nyata terhadap luas daun dimana permukaan daun tanaman yang ditanam dengan jumlah tiga biji per lubang tanam paling luas dan berbeda nyata dengan luas daun tanaman yang ditanam dengan jumlah satu biji per lubang tanam tetapi tidak berbeda nyata dengan luas daun tanaman yang ditanam dengan jumlah dua biji per lubang tanam.

Tabel 3. Luas Daun $\left(\mathrm{cm}^{2}\right)$

\begin{tabular}{ccccc}
\hline Model & \multicolumn{2}{c}{ Jumlah Biji Per Lubang Tanam } & \multirow{2}{*}{ Rerata } \\
\cline { 2 - 4 } Penyimpanan & Satu & Dua & Tiga & \\
\hline Klobot & $1001,3 \mathrm{~d}$ & $1697,3 \mathrm{c}$ & $2840,0 \mathrm{a}$ & $1846,2 \mathrm{a}$ \\
Lumbung & $1034,7 \mathrm{~d}$ & $2573,0 \mathrm{ab}$ & $2193,0 \mathrm{bc}$ & $1933,6 \mathrm{a}$ \\
Drum & $1480,7 \mathrm{~cd}$ & $1762,3 \mathrm{c}$ & $2292,3 \mathrm{bc}$ & $1845,1 \mathrm{a}$ \\
\hline Rerata & $1172,2 \mathrm{~b}$ & $2010,9 \mathrm{a}$ & $2441,8 \mathrm{a}$ & $(-)$ \\
\hline Keterangan : & Angka pada baris dan kolom yang diikuti dengan huruf yang sama \\
& tidak berbeda nyata menurut uji DMRT $\alpha$ 5\%.. ( - ) : Tidak terjadi \\
& interaksi antar faktor
\end{tabular}

\subsection{Jumlah Tongkol Per Tanaman}

Setiap tanaman yang benihnya disimpan dengan cara klobot, dalam lumbung maupun dalam drum rata-rata memiliki dua tongkol pada setiap tanamannya, sedangkan penanaman dengan satu biji per lubang tanam menghasilkan rata-rata satu tongkol, penanaman dengan dua biji per lubang tanam menghasilkan rata-rata dua tongkol, demikian juga penanaman dengan tiga biji per lubang tanam menghasilkan rata-rata tiga tongkol pada setiap tanamannya seperti yang terlihat pada Tabel 4 .

\section{Tabel 4. Jumlah Tongkol Per Tanaman}

\begin{tabular}{ccccc}
\hline Model & \multicolumn{2}{c}{ Jumlah Biji Per Lubang Tanam } & \multirow{2}{*}{ Rerata } \\
\cline { 2 - 4 } Penyimpanan & Satu & Dua & Tiga & \\
\hline Klobot & 1,0 & 2,0 & 3,0 & 2,0 \\
Lumbung & 1,0 & 2,0 & 3,0 & 2,0 \\
Drum & 1,0 & 2,0 & 3,0 & 2,0 \\
\hline Rerata & 1,0 & 2,0 & 3,0 & \\
\hline
\end{tabular}

\subsection{Panjang Tongkol}

Hasil sidik ragam (Anova) menunjukkan terjadi pengaruh interaksi antara model penyimpanan benih dan jumlah biji per lubang tanam terhadap panjang tongkol dimana tanaman jagung yang benihnya disimpan dengan cara klobot kemudian ditanam dengan jumlah satu biji per lubang tanam memiliki tongkol yang paling panjang dan berbeda nyata dengan panjang tongkol tanaman dari kombinasi perlakuan yang lainnya.

Model penyimpanan benih juga berpengaruh secara nyata terhadap panjang tongkol dimana tanaman yang sebelum ditanam benihnya disimpan dengan cara klobot menghasilkan tongkol yang paling panjang dan berbeda nyata dengan panjang tongkol tanaman yang sebelum ditanam benihnya disimpan dalam lumbung. Jumlah biji per lubang tanam tidak berpengaruh nyata terhadap panjang tongkol tetapi data Tabel 5. menunjukkan bahwa tanaman yang ditanam dengan jumlah satu biji per lubang tanam menghasilkan tongkol yang cenderung lebih panjang sedangkan tanaman yang ditanam dengan jumlah tiga biji per lubang tanam menghasilkan tongkol yang paling pendek.

Tabel 5. Panjang Tongkol (cm)

\begin{tabular}{ccccc}
\hline Model & \multicolumn{2}{c}{ Jumlah Biji Per Lubang Tanam } & \multirow{2}{*}{ Rerata } \\
\cline { 2 - 4 } Penyimpanan & Satu & Dua & Tiga & \\
\hline Klobot & $16,6 \mathrm{a}$ & $13,4 \mathrm{~b}$ & $12,9 \mathrm{~b}$ & $14,3 \mathrm{a}$ \\
Lumbung & $13,1 \mathrm{~b}$ & $13,0 \mathrm{~b}$ & $12,8 \mathrm{~b}$ & $12,9 \mathrm{~b}$ \\
Drum & $12,9 \mathrm{~b}$ & $13,6 \mathrm{~b}$ & $13,1 \mathrm{~b}$ & $13,2 \mathrm{ab}$ \\
\hline Rerata & $14,2 \mathrm{a}$ & $13,3 \mathrm{a}$ & $13,0 \mathrm{a}$ & $(+)$ \\
\hline Keterangan : & Angka pada baris dan kolom yang diikuti dengan huruf yang sama \\
& tidak berbeda nyata menurut uji DMRT $\alpha \% . .(+)$ : Terjadi interaksi \\
& antar faktor
\end{tabular}

\subsection{Diameter Tongkol}

Hasil sidik ragam (Anova) menunjukkan tidak terjadi pengaruh interaksi antara model penyimpanan benih dan jumlah biji per lubang tanam terhadap diameter tongkol. Pengaruh utama model penyimpanan benih maupun jumlah biji per lubang tanam juga tidak terjadi terhadap diameter tongkol.

\section{Tabel 6. Diameter Tongkol (cm)}

\begin{tabular}{ccccc}
\hline Model & \multicolumn{2}{c}{ Jumlah Biji Per Lubang Tanam } & \multirow{2}{*}{ Rerata } \\
\cline { 2 - 4 } Penyimpanan & Satu & Dua & Tiga & \\
\hline Klobot & $4,6 \mathrm{a}$ & $4,4 \mathrm{a}$ & $4,1 \mathrm{a}$ & $4,3 \mathrm{a}$ \\
Lumbung & $4,3 \mathrm{a}$ & $4,3 \mathrm{a}$ & $4,4 \mathrm{a}$ & $4,3 \mathrm{a}$ \\
Drum & $4,5 \mathrm{a}$ & $4,2 \mathrm{a}$ & $4,8 \mathrm{a}$ & $4,5 \mathrm{a}$ \\
\hline Rerata & $4,4 \mathrm{a}$ & $4,3 \mathrm{a}$ & $4,4 \mathrm{a}$ & $(-)$ \\
\hline Keterangan : & $\begin{array}{l}\text { Angka pada baris dan kolom yang diikuti dengan huruf yang sama } \\
\\
\end{array}$ & tidak berbeda nyata menurut uji DMRT $\alpha$ 5\%.. ( - ) : Tidak terjadi \\
& interaksi antar faktor
\end{tabular}

Data Tabel 6. menunjukkan bahwa diameter tongkol dari tanaman yang sebelum ditanam benihnya disimpan dalam drum cenderung lebih besar sedangkan diameter tongkol dari tanaman yang sebelum ditanam benihnya disimpan dengan cara klobot dan disimpan dalam drum sama besar. Tanaman yang ditanam dengan jumlah satu biji dan dua biji per lubang tanam menghasilkan diameter tongkol yang cenderung lebih besar sedangkan tanaman yang ditanam dengan jumlah dua biji per lubang tanam menghasilkan tongkol yang lebih kecil.

\subsection{Jumlah Baris Per Tongkol}

Hasil sidik ragam (Anova) menunjukkan terjadi pengaruh interaksi antara model penyimpanan benih dan jumlah biji per lubang tanam terhadap jumlah baris per tongkol dimana tanaman jagung yang benihnya disimpan dengan cara klobot kemudian ditanam dengan jumlah satu biji per lubang tanam memiliki jumlah baris setiap tongkol yang paling banyak dan berbeda nyata dengan jumlah baris per tongkol dari tanaman jagung yang benihnya disimpan dalam drum kemudian ditanam dengan jumlah dua biji per lubang tanam tetapi tidak berbeda nyata dengan jumlah baris per tongkol tanaman dari kombinasi perlakuan yang lainnya.

\section{Tabel 7. Jumlah Baris Per Tongkol}

\begin{tabular}{ccccc}
\hline Model & \multicolumn{2}{c}{ Jumlah Biji Per Lubang Tanam } & \multirow{2}{*}{ Rerata } \\
\cline { 2 - 4 } Penyimpanan & Satu & Dua & Tiga & \\
\hline Klobot & $14,4 \mathrm{a}$ & $13,3 \mathrm{a}$ & $13,1 \mathrm{a}$ & $13,6 \mathrm{a}$ \\
Lumbung & $13,5 \mathrm{a}$ & $13,4 \mathrm{a}$ & $13,9 \mathrm{a}$ & $13,6 \mathrm{a}$ \\
Drum & $13,3 \mathrm{a}$ & $12,9 \mathrm{~b}$ & $13,5 \mathrm{a}$ & $13,3 \mathrm{a}$ \\
\hline Rerata & $13,7 \mathrm{a}$ & $13,2 \mathrm{~b}$ & $13,5 \mathrm{~b}$ & $(+)$ \\
\hline Keterangan : & Angka pada baris dan kolom yang diikuti dengan huruf yang sama \\
& tidak berbeda nyata menurut uji DMRT $\alpha \%$... (+) : Terjadi interaksi \\
& antar faktor &
\end{tabular}

Model penyimpanan benih tidak berpengaruh secara nyata terhadap jumlah baris per tongkol tetapi data Tabel 7. menunjukkan bahwa tanaman yang sebelum ditanam benihnya disimpan dengan cara klobot dan dalam lumbung menghasilkan baris dalam setiap tongkol yang cenderung lebih banyak dibanding tanaman yang sebelum ditanam benihnya disimpan dalam drum. Sebaliknya jumlah biji per lubang tanam berpengaruh nyata terhadap jumlah baris per tongkol dimana tanaman yang ditanam dengan jumlah satu biji per lubang tanam menghasilkan baris dalam setiap tongkol yang paling banyak dan berbeda nyata dengan jumlah baris per tongkol tanaman yang ditanam dengan jumlah dua biji maupun tiga biji per lubang tanam.

\subsection{Jumlah Biji Per Baris}

Hasil sidik ragam (Anova) menunjukkan tidak terjadi pengaruh interaksi antara model penyimpanan benih dan jumlah biji per lubang tanam terhadap jumlah biji per baris.

Model penyimpanan benih juga tidak berpengaruh secara nyata terhadap jumlah biji per baris tetapi data Tabel 8. menunjukkan bahwa tanaman yang sebelum ditanam benihnya disimpan dengan cara klobot menghasilkan biji setiap baris yang cenderung lebih banyak dibanding tanaman yang sebelum ditanam benihnya disimpan dalam drum maupun tanaman yang sebelum ditanam benihnya disimpan dalam lumbung yang menghasilkan biji dalam 
setiap baris paling sedikit. Sebaliknya jumlah biji per lubang tanam berpengaruh nyata terhadap jumlah biji per baris dimana tanaman yang ditanam dengan jumlah satu biji per lubang tanam menghasilkan biji setiap baris yang paling banyak dan berbeda nyata dengan jumlah biji per baris tanaman yang ditanam dengan jumlah tiga biji per lubang tanam.

Tabel 8. Jumlah Biji Per Baris

\begin{tabular}{|c|c|c|c|c|}
\hline \multirow{2}{*}{$\begin{array}{c}\text { Model } \\
\text { Penyimpanan }\end{array}$} & \multicolumn{3}{|c|}{ Jumlah Biji Per Lubang Tanam } & \multirow{2}{*}{ Rerata } \\
\hline & Satu & Dua & Tiga & \\
\hline Klobot & $27,5 \mathrm{a}$ & $24,9 \mathrm{a}$ & $22,0 \mathrm{a}$ & 24,8 a \\
\hline Lumbung & $24,5 \mathrm{a}$ & $23,6 \mathrm{a}$ & $24,2 \mathrm{a}$ & $24,1 \mathrm{a}$ \\
\hline Drum & $25,4 \mathrm{a}$ & $24,8 \mathrm{a}$ & $23,2 \mathrm{a}$ & $24,5 \mathrm{a}$ \\
\hline Rerata & $25,8 \mathrm{a}$ & $24,4 \mathrm{ab}$ & $23,2 \mathrm{~b}$ & $(-)$ \\
\hline Keterangan & $\begin{array}{l}\text { Angka pada } \\
\text { tidak berbed } \\
\text { interaksi ant }\end{array}$ & $\begin{array}{l}\text { kolom } \\
\text { enurut }\end{array}$ & $\begin{array}{l}\alpha 5^{\circ} \\
\text { ti d }\end{array}$ & $\begin{array}{l}\text { lang } \\
\text { lak te }\end{array}$ \\
\hline
\end{tabular}

\subsection{Jumlah Tongkol Per Petak}

Hasil sidik ragam (Anova) menunjukkan tidak terjadi pengaruh interaksi antara model penyimpanan benih dan jumlah biji per lubang tanam terhadap jumlah tongkol per petak.

Model penyimpanan benih juga tidak berpengaruh secara nyata terhadap jumlah tongkol per petak tetapi data Tabel 9. menunjukkan bahwa tanaman yang sebelum ditanam benihnya disimpan dengan cara klobot menghasilkan tongkol setiap petak yang cenderung lebih banyak dibanding tanaman yang sebelum ditanam benihnya disimpan dalam lumbung maupun tanaman yang sebelum ditanam benihnya disimpan dalam drum yang menghasilkan tongkol dalam setiap petak paling sedikit. Sebaliknya jumlah biji per lubang tanam berpengaruh nyata terhadap jumlah tongkol per petak dimana tanaman yang ditanam dengan jumlah tiga biji per lubang tanam menghasilkan tongkol setiap petak yang paling banyak dan berbeda nyata dengan jumlah tongkol per petak dari tanaman yang ditanam dengan jumlah dua biji per lubang tanam maupun tanaman yang ditanam dengan jumlah satu biji per lubang tanam yang menghasilkan tongkol setiap petak yang paling sedikit.

Tabel 9. Jumlah Tongkol Per Petak

\begin{tabular}{|c|c|c|c|c|}
\hline \multirow{2}{*}{$\begin{array}{c}\text { Model } \\
\text { Penyimpanan }\end{array}$} & \multicolumn{3}{|c|}{ Jumlah Biji Per Lubang Tanam } & \multirow{2}{*}{ Rerata } \\
\hline & Satu & Dua & Tiga & \\
\hline Klobot & $30,0 \mathrm{~b}$ & $67,0 \mathrm{a}$ & $100,3 \mathrm{a}$ & $65,8 \mathrm{a}$ \\
\hline Lumbung & $30,3 \mathrm{~b}$ & $62,7 \mathrm{ab}$ & $97,3 \mathrm{a}$ & $63,4 \mathrm{a}$ \\
\hline Drum & $30,0 \mathrm{~b}$ & $65,0 \mathrm{a}$ & $99,7 \mathrm{a}$ & $64,9 \mathrm{a}$ \\
\hline Rerata & $30,1 \mathrm{c}$ & $64,9 \mathrm{~b}$ & $99,1 \mathrm{a}$ & $(-)$ \\
\hline Keterangan : & $\begin{array}{l}\text { Angka pada } \\
\text { tidak berbed } \\
\text { interaksi ant }\end{array}$ & $\begin{array}{l}\text { kolom } \\
\text { nenurut }\end{array}$ & $\begin{array}{l}\text { liikuti de } \\
\text { IRTa } 5 \%\end{array}$ & $\begin{array}{l}\text { f yang } \\
\text { Tidak }\end{array}$ \\
\hline
\end{tabular}

\subsection{Berat Pipilan Kering Per Tanaman}

Hasil sidik ragam (Anova) menunjukkan tidak terjadi pengaruh interaksi antara model penyimpanan benih dan jumlah biji per lubang tanam terhadap berat pipilan kering per tanaman.

Model penyimpanan benih juga tidak berpengaruh secara nyata terhadap berat pipilan kering per tanaman tetapi data Tabel 10. menunjukkan bahwa tanaman yang sebelum ditanam benihnya disimpan dengan cara klobot menghasilkan pipilan kering setiap tanaman yang cenderung lebih berat dibanding tanaman yang sebelum ditanam benihnya disimpan dalam drum maupun tanaman yang sebelum ditanam benihnya disimpan dalam lumbung yang menghasilkan pipilan kering setiap tanaman paling ringan. Sebaliknya jumlah biji per lubang tanam berpengaruh nyata terhadap berat pipilan kering per tanaman dimana tanaman yang ditanam dengan jumlah tiga biji per lubang tanam menghasilkan pipilan kering per tanaman yang paling berat dan berbeda nyata dengan berat pipilan kering dari tanaman yang ditanam dengan jumlah dua biji per lubang tanam maupun tanaman yang ditanam dengan jumlah satu biji per lubang tanam yang menghasilkan pipilan kering per tanaman yang paling ringan.

Tabel 10. Berat Pipilan Kering Per Tanaman (g)

\begin{tabular}{|c|c|c|c|c|}
\hline \multirow{2}{*}{$\begin{array}{c}\text { Model } \\
\text { Penyimpanan }\end{array}$} & \multicolumn{3}{|c|}{ Jumlah Biji Per Lubang Tanam } & \multirow[b]{2}{*}{ Rerata } \\
\hline & Satu & Dua & Tiga & \\
\hline Klobot & $135,3 \mathrm{e}$ & $210,0 \mathrm{c}$ & $245,3 \mathrm{~b}$ & $196,9 \mathrm{a}$ \\
\hline Lumbung & $100,3 \mathrm{f}$ & $174,3 \mathrm{~d}$ & $294,3 \mathrm{a}$ & $189,7 \mathrm{a}$ \\
\hline Drum & $108,3 \mathrm{f}$ & $201,0 \mathrm{~cd}$ & $279,3 \mathrm{a}$ & $196,2 \mathrm{a}$ \\
\hline Rerata & $114,7 \mathrm{c}$ & $195,1 \mathrm{~b}$ & $273,0 \mathrm{a}$ & $(-)$ \\
\hline Keterangan & $\begin{array}{l}\text { Angka pada ba } \\
\text { tidak berbeda } \\
\text { interaksi antar }\end{array}$ & lom yal & $\begin{array}{l}\text { dengar } \\
5 \%\end{array}$ & \\
\hline
\end{tabular}

\subsection{Berat $100 \mathrm{Biji}$}

Hasil sidik ragam (Anova) menunjukkan tidak terjadi pengaruh interaksi antara model penyimpanan benih dan jumlah biji per lubang tanam terhadap berat 100 biji.
Tabel 11. Berat 100 Biji (g)

\begin{tabular}{ccccc}
\hline Model & \multicolumn{2}{c}{ Jumlah Biji Per Lubang Tanam } & \multirow{2}{*}{ Rerata } \\
\cline { 2 - 4 } Penyimpana & Satu & Dua & Tiga & \\
\hline Klobot & $31,0 \mathrm{a}$ & $26,5 \mathrm{ab}$ & $24,4 \mathrm{~b}$ & $27,3 \mathrm{a}$ \\
Lumbung & $27,3 \mathrm{ab}$ & $26,3 \mathrm{~b}$ & $26,1 \mathrm{~b}$ & $26,6 \mathrm{a}$ \\
Drum & $31,5 \mathrm{a}$ & $25,5 \mathrm{~b}$ & $27,0 \mathrm{ab}$ & $28,0 \mathrm{a}$ \\
\hline Rerata & $29,9 \mathrm{a}$ & $26,1 \mathrm{~b}$ & $25,8 \mathrm{~b}$ & $(-)$ \\
\hline Keterangan : & Angka pada baris dan kolom yang diikuti dengan huruf yang sama \\
& tidak berbeda nyata menurut uji DMRT $\alpha \%$ 5\%.. ( - ) : Tidak terjadi \\
& interaksi antar faktor
\end{tabular}

Model penyimpanan benih tidak berpengaruh secara nyata terhadap berat 100 biji tetapi data Tabel 11. menunjukkan bahwa tanaman yang sebelum ditanam benihnya disimpan dalam drum menghasilkan setiap 100 biji yang cenderung lebih berat dibanding tanaman yang sebelum ditanam benihnya disimpan dengan cara klobot maupun tanaman yang sebelum ditanam benihnya disimpan dalam lumbung yang menghasilkan setiap 100 biji yang paling ringan. Sebaliknya jumlah biji per lubang tanam berpengaruh nyata terhadap berat 100 biji dimana tanaman yang ditanam dengan jumlah satu biji per lubang tanam menghasilkan setiap 100 biji yang paling berat dan berbeda nyata dengan berat 100 biji dari tanaman yang ditanam dengan jumlah dua biji per lubang tanam maupun tanaman yang ditanam dengan jumlah tiga biji per lubang tanam yang menghasilkan berat 100 biji yang paling ringan.

\subsection{Berat Pipilan Kering Per Petak}

Hasil sidik ragam (Anova) menunjukkan tidak terjadi pengaruh interaksi antara model penyimpanan benih dan jumlah biji per lubang tanam terhadap berat pipilan kering per petak.

\section{Tabel 12. Berat Pipilan Kering Per Petak (t/ha)}

\begin{tabular}{ccccc}
\hline Model & \multicolumn{2}{c}{ Jumlah Biji Per Lubang Tanam } & \multirow{2}{*}{ Rerata } \\
\cline { 2 - 4 } Penyimpanan & Satu & Dua & Tiga & \\
\hline Klobot & $1,578 \mathrm{~b}$ & $2,400 \mathrm{ab}$ & $3,178 \mathrm{a}$ & $2,385 \mathrm{a}$ \\
Lumbung & $1,600 \mathrm{~b}$ & $2,422 \mathrm{a}$ & $3,022 \mathrm{a}$ & $2,348 \mathrm{a}$ \\
Drum & $1,511 \mathrm{~b}$ & $2,444 \mathrm{a}$ & $3,044 \mathrm{a}$ & $2,333 \mathrm{a}$ \\
\hline Rerata & $1,563 \mathrm{c}$ & $2,422 \mathrm{~b}$ & $3,081 \mathrm{a}$ & $(-)$ \\
\hline Keterangan : & $\begin{array}{l}\text { Angka pada baris dan kolom yang diikuti dengan huruf yang sama } \\
\\
\end{array}$ \\
& tidak berbeda nyata menurut uji DMRT $\alpha$ 5\%.. ( - ) : Tidak terjadi \\
& interaksi antar faktor
\end{tabular}

Model penyimpanan benih tidak berpengaruh secara nyata terhadap berat pipilan kering per petak tetapi data Tabel 12. menunjukkan bahwa tanaman yang sebelum ditanam benihnya disimpan dengan cara klobot menghasilkan pipilan kering setiap petak yang cenderung lebih berat dibanding tanaman yang sebelum ditanam benihnya disimpan dalam lumbung maupun tanaman yang sebelum ditanam benihnya disimpan dalam drum yang menghasilkan pipilan kering setiap petak paling ringan. Sebaliknya jumlah biji per lubang tanam berpengaruh nyata terhadap berat pipilan kering per petak dimana tanaman yang ditanam dengan jumlah tiga biji per lubang tanam menghasilkan pipilan kering per petak yang paling berat dan berbeda nyata dengan berat pipilan kering per petak dari tanaman yang ditanam dengan jumlah dua biji per lubang tanam maupun tanaman yang ditanam dengan jumlah satu biji per lubang tanam yang menghasilkan pipilan kering per petak yang paling ringan.

\subsection{Berat Segar Berangkasan}

Hasil sidik ragam (Anova) menunjukkan tidak terjadi pengaruh interaksi antara model penyimpanan benih dan jumlah biji per lubang tanam terhadap berat segar berangkasan.

$\underline{\text { Tabel 13. Berat Segar Berangkasan (t/ha) }}$

\begin{tabular}{|c|c|c|c|c|}
\hline \multirow{2}{*}{$\begin{array}{c}\text { Model } \\
\text { Penyimpanan }\end{array}$} & \multicolumn{3}{|c|}{ Jumlah Biji Per Lubang Tanam } & \multirow{2}{*}{ Rerata } \\
\hline & Satu & Dua & Tiga & \\
\hline Klobot & $2,622 \mathrm{a}$ & $3,244 \mathrm{a}$ & $3,600 \mathrm{a}$ & $3,156 \mathrm{a}$ \\
\hline Lumbung & $1,822 \mathrm{a}$ & $3,000 \mathrm{a}$ & $3,800 \mathrm{a}$ & $2,874 \mathrm{a}$ \\
\hline Drum & $2,400 \mathrm{a}$ & $2,800 \mathrm{a}$ & $3,511 \mathrm{a}$ & $2,904 \mathrm{a}$ \\
\hline Rerata & $2,281 \mathrm{~b}$ & $3,015 \mathrm{a}$ & $3,637 \mathrm{a}$ & $(-)$ \\
\hline Keterangan : & $\begin{array}{l}\text { Angka pada } \\
\text { tidak berbeda } \\
\text { interaksi antar }\end{array}$ & $\begin{array}{l}\mathrm{n} \text { kolom } \mathrm{y} \\
\text { menurut } \mathrm{u}\end{array}$ & $\begin{array}{l}\text { kuti deng } \\
\text { RT } \alpha 5 \% . .\end{array}$ & ang $\mathrm{s}$ \\
\hline
\end{tabular}

Model penyimpanan benih tidak berpengaruh secara nyata terhadap berat segar berangkasan tetapi data Tabel 13. menunjukkan bahwa tanaman yang sebelum ditanam benihnya disimpan dengan cara klobot memiliki berangkasan segar yang cenderung lebih berat dibanding tanaman yang sebelum ditanam benihnya disimpan dalam drum maupun tanaman yang sebelum ditanam benihnya disimpan dalam lumbung yang memiliki berangkasan segar yang paling ringan. Sebaliknya jumlah biji per lubang tanam berpengaruh nyata terhadap berat segar berangkasan dimana tanaman yang ditanam dengan jumlah tiga biji per lubang tanam memiliki berangkasan segar yang paling berat dan berbeda nyata dengan berat segar berangkasan dari tanaman yang ditanam dengan jumlah satu biji per lubang tanam yang memiliki berangkasan segar paling ringan. 


\subsection{Berat Kering Berangkasan}

Hasil sidik ragam (Anova) menunjukkan tidak terjadi pengaruh interaksi antara model penyimpanan benih dan jumlah biji per lubang tanam terhadap berat kering berangkasan tetapi hasil uji lanjut menunjukkan bahwa berangkasan kering dari tanaman yang benihnya disimpan dengan cara klobot kemudian ditanam dengan jumlah tiga biji per lubang tanam paling berat dan berbeda nyata dengan berangkasan kering tanaman yang benihnya disimpan dengan cara klobot kemudian ditanam dengan jumlah satu biji per lubang tanam tetapi tidak berbeda nyata dengan berat kering berangkasan dari kombinasi perlakuan yang lainnya.

Tabel 14. Berat Kering Berangkasan (t/ha)

\begin{tabular}{ccccc}
\hline Model & \multicolumn{2}{c}{ Jumlah Biji Per Lubang Tanam } & \multirow{2}{*}{ Rerata } \\
\cline { 2 - 4 } Penyimpanan & Satu & Dua & Tiga & \\
\hline Klobot & $1,400 \mathrm{~b}$ & $1,800 \mathrm{ab}$ & $2,600 \mathrm{a}$ & $1,900 \mathrm{a}$ \\
Lumbung & $1,200 \mathrm{ab}$ & $2,100 \mathrm{ab}$ & $2,500 \mathrm{ab}$ & $1,900 \mathrm{a}$ \\
Drum & $1,600 \mathrm{ab}$ & $1,900 \mathrm{ab}$ & $2,500 \mathrm{ab}$ & $2,000 \mathrm{a}$ \\
\hline Rerata & $1,400 \mathrm{c}$ & $2,000 \mathrm{~b}$ & $2,500 \mathrm{a}$ & $(-)$ \\
\hline Keterangan : & $\begin{array}{l}\text { Angka pada baris dan kolom yang diikuti dengan huruf yang sama } \\
\end{array}$ & tidak berbeda nyata menurut uji DMRT $\alpha \%$ 5\%.. ( - ) : Tidak terjadi \\
& interaksi antar faktor
\end{tabular}

Model penyimpanan benih tidak berpengaruh secara nyata terhadap berat kering berangkasan tetapi data Tabel 14. menunjukkan bahwa tanaman yang sebelum ditanam benihnya disimpan dalam drum memiliki berangkasan kering yang cenderung lebih berat dibanding tanaman yang sebelum ditanam benihnya disimpan dalam drum maupun tanaman yang sebelum ditanam benihnya disimpan dengan cara klobot. Sebaliknya jumlah biji per lubang tanam berpengaruh nyata terhadap berat kering berangkasan dimana tanaman yang ditanam dengan jumlah tiga biji per lubang tanam memiliki berangkasan kering yang paling berat dan berbeda nyata dengan berat kering berangkasan dari tanaman yang ditanam dengan jumlah dua biji per lubang tanam maupun tanaman yang ditanam dengan jumlah satu biji per lubang tanam yang memiliki berangkasan kering paling ringan.

\subsection{Indeks Panen}

Hasil sidik ragam (Anova) menunjukkan tidak terjadi pengaruh interaksi antara model penyimpanan benih dan jumlah biji per lubang tanam terhadap indeks panen. Pengaruh utama model penyimpanan benih maupun jumlah biji per lubang tanam juga tidak terjadi terhadap indeks panen tetapi data Tabel 15. menunjukkan bahwa tanaman yang sebelum ditanam benihnya disimpan dalam lumbung memiliki nilai indeks panen yang cenderung lebih tinggi sedangkan indeks panen dari tanaman yang sebelum ditanam benihnya disimpan dengan dalam drum paling rendah. Tanaman yang ditanam dengan jumlah dua biji per lubang tanam memiliki nilai indeks panen yang cenderung lebih tinggi sedangkan tanaman yang ditanam dengan jumlah satu biji per lubang tanam memiliki indeks panen paling rendah.

Tabel 15. Indeks Panen (\%)

\begin{tabular}{ccccc}
\hline Model & \multicolumn{2}{c}{ Jumlah Biji Per Lubang Tanam } & \multirow{2}{*}{ Rerata } \\
\cline { 2 - 4 } Penyimpanan & Satu & Dua & Tiga & \\
\hline Klobot & $52,9 \mathrm{a}$ & $56,5 \mathrm{a}$ & $55,6 \mathrm{a}$ & $55,0 \mathrm{a}$ \\
Lumbung & $56,4 \mathrm{a}$ & $54,6 \mathrm{a}$ & $55,1 \mathrm{a}$ & $55,4 \mathrm{a}$ \\
Drum & $49,3 \mathrm{a}$ & $57,3 \mathrm{a}$ & $55,3 \mathrm{a}$ & $54,0 \mathrm{a}$ \\
\hline Rerata & $52,9 \mathrm{a}$ & $56,1 \mathrm{a}$ & $55,3 \mathrm{a}$ & $(-)$ \\
\hline Keterangan : & Angka pada baris dan kolom yang diikuti dengan huruf yang sama \\
& tidak berbeda nyata menurut uji DMRT $\alpha \%$ 5\%. ( - ) : Tidak terjadi \\
& interaksi antar faktor
\end{tabular}

\subsection{Pembahasan}

Tanaman jagung yang sebelum ditanam benihnya disimpan dalam dapur dengan pengasapan (klobot) memiliki pertumbuhan vegetatif yang lebih baik berupa tanaman yang lebih tinggi dengan batang yang lebih besar meskipun permukaan daunnya tidak terlalu luas, serta berangkasan segar yang lebih berat. Selain pertumbuhan vegetatif, hasil yang dicapai juga lebih baik seperti tongkol yang lebih panjang, jumlah baris per tongkol, jumlah biji per baris dan jumlah tongkol setiap petak yang lebih banyak, pipilan kering per tanaman yang lebih berat sehingga hasil berupa pipilan kering setiap petak juga lebih berat. Secara umum model penyimpanan benih dalam dapur dengan pengasapan (klobot) lebih baik untuk pertumbuhan dan hasil jagung dibandingkan penyimpanan benih dalam lumbung atau drum. Hal ini sesuai dengan pernyataan Murdolelono dan Hosang (2004) bahwa model penyimpanan jagung yang dapat memberikan pertumbuhan dan hasil yang baik adalah penyimpanan jagung bertongkol dengan klobot.

Tanaman jagung yang ditanam dengan jumlah tiga benih per lubang tanam memiliki ukuran yang tidak terlalu tinggi tetapi memiliki diameter batang yang juga sama besar dengan diameter batang tanaman jagung yang ditanam dengan jumlah satu benih per lubang tanam. Penanaman tiga biji per lubang tanam secara umum meningkatkan jumlah individu pada setiap lubang tanam maupun jumlah individu setiap petaknya sehingga permukaan daun tanaman lebih luas, jumlah tongkol setiap tanaman maupun setiap petak menjadi lebih banyak. Tongkol yang terbentuk lebih pendek tetapi dengan diameter yang sama seperti diameter tongkol tanaman yang ditanam dengan jumlah satu biji per lubang tanam sehingga baris dalam setiap tongkol tidak terlalu banyak dan biji dalam setiap barisnya paling sedikit dengan berat 100 biji yang paling ringan. Hal ini membuktikan bahwa penanaman tiga biji per lubang tanam menghasilkan biji dengan ukuran yang kecil, meski demikian karena memiliki individu tanaman dalam jumlah yang lebih banyak sehingga pipilan kering yang dihasilkan setiap tanaman maupun setiap petaknya paling berat. Penanaman jagung dengan jumlah tiga biji per lubang tanam juga memberikan berangkasan segar maupun kering yang lebih berat.

\section{Simpulan}

Dari hasil dan pembahasan yang dilakukan, maka dapat disimpulkan beberapa hal sebagai berikut :

a. Interaksi antara model penyimpanan benih dan jumlah biji per lubang tanam hanya terjadi terhadap parameter tinggi tanaman 35 HST, panjang tongkol dan jumlah baris per tongkol.

b. Model penyimpanan dalam klobot berpengaruh nyata terhadap diameter batang 56 HST dan panjang tongkol, sedangkan jumlah biji per lubang tanam berpengaruh nyata terhadap tinggi tanaman 56 HST, luas daun, jumlah baris per tongkol, jumlah biji per baris, jumlah tongkol per petak, berat pipilan kering per tanaman maupun per petak, berat 100 biji dan berat segar maupun kering berangkasan.

c. Penyimpanan benih dengan cara klobot memberikan hasil jagung tertinggi sebesar 2,385 t/ha. Penanaman dengan jumlah tiga biji per lubang tanam memberikan hasil jagung tertinggi yakni 3,178 t/ha.

\section{Pustaka}

Agustinus. 2008. Kajian Vormulasi Isotermik Sorpsi Air Bubur Jagung Insan. Sekolah Pascasarjana. Institut Pertanian Bogor.

Berkelaar D. 2001. Sistem Intensifikasi Padi (The system of Rice intensificasion-SRI). Buletin ECHO Development Notes, January 2001, Issue 70. Terjemahan bebas oleh Indro Surono, staf ELSPPAT, Bogor, Indonesia.

BPS NTT. 2014. Nusa Tenggara Timur Dalam Angka. BPS NTT. Kupang. Gomez K A dan Gomez A A. 1995. Prosedur Statistik untuk Penelitian Pertanian. Edisi ke 2. Jakarta: UI Press.

Murdolelono dan Hosang. 2004. Pengaruh teknik penyimpanan terhadap jagung

Rinsema WJ. 1993. Pupuk dan Cara Pemupukan. Bhratara Karya Aksa. Jakarta. Suarni. 2001. Sosial Ekonomi Nasional (Susenas) Tahun 2008

Subagio dan Aqil. 2013. Tanaman Pangan.

Sutopo L. 2002. Teknologi Benih. Raja Grafindo Persada. Jakarta 